\title{
Ceragenins exhibiting promising antimicrobial activity against various multidrug resistant Gram negative bacteria
}

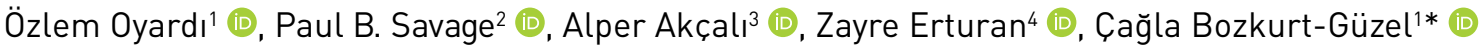 \\ 'Department of Pharmaceutical Microbiology, Faculty of Pharmacy, Istanbul University, 34116, Istanbul, Turkey \\ 2Department of Chemistry and Biochemistry, Brigham Young University, 84602, Provo, Utah, USA, \\ ${ }^{3}$ Department of Medical Microbiology, Faculty of Medicine, Canakkale Onsekiz Mart University, 17020, Canakkale, Turkey \\ ${ }^{4}$ Department of Medical Microbiology, Faculty of Medicine, Istanbul University, 34093, Istanbul, Turkey
}

Cite this article as: Oyardı Ö, Savage PB, Akçalı A, Erturan Z, Bozkurt-Güzel C.. (2018) Ceragenins exhibiting promising antimicrobial activity against various multidrug resistant Gram negative bacteria. Istanbul J Pharm 48 (3): 68-72.

\section{ABSTRACT}

Ceragenins are novel promising agents for the treatment of infections caused by multi-drug resistant microorganisms. Since colistin resistance has become a worldwide problem, the need for new treatment agents has been increasing steadily. Therefore, this study aimed to investigate in vitro antimicrobial activities of ceragenins (Cationic Steroid Antibiotics) (CSA-8, CSA-13, CSA-142 and CSA-192) against multidrug resistant Gram negative isolates from Turkey. Experiments were performed by using broth microdilution method against Klebsiella pneumoniae, Morganella morganii, Pseudomonas aeruginosa and Stenotrophomonas maltophilia isolates. All microorganisms except for three isolates were identified as multidrug resistant. Among tested ceragenins, CSA-13 showed the best results (MIC: $8-64 \mu \mathrm{g} / \mathrm{ml}$ ). Nevertheless, the antimicrobial activity of CSA-8 was not significant. In conclusion, ceragenins appear to be a good candidate as antimicrobial therapy in the presence of multidrug (including colistin) resistant microorganisms.
\end{abstract}

Keywords: Ceragenins, colistin resistance, gram negative pathogens

\section{INTRODUCTION}

Antibiotic resistance is defined as the loss of activity of antibiotics against microorganisms. Antibiotic resistant bacteria, especially Gram negative bacteria, cause an increasing concern and antibiotic options used in the treatment of infectious diseases have been gradually decreasing (Zaman et al. 2017). For a long time now, colistin has been used by clinicians as only option to treat these infections. However, colistin resistance has been reported due to its widespread use in many countries. (Marchaim et al. 2011; Ah et al. 2014; Rojas et al. 2016; Sonnevend et al. 2016; Otter et al. 2017; Rossi et al. 2017). Therefore, discovering novel antimicrobials are essential in continuing to fight against antibiotic resistant bacteria.

Some of the new generation of promising agents are antimicrobial peptides (AMPs) (Döşler 2017) and ceragenins (Lai et al. 2008; Bolla et al. 2011). AMPs display broad-spectrum antimicrobial activities by interacting with the bacterial cell membrane. On the other hand, the clinical use of AMPs is problematic due to the difficulty of its synthesis and the lack of stability. Furthermore, AMP resistance may occur through some mechanisms such as secretion of proteases, release of AMP degrading enzymes, active efflux (Band and Weiss 2014; Döşler 2017). Ceragenins, Cationic Steroid Antibiotics (CSA), which are synthetic cholic acid derivatives, have the same mechanism of action as natural AMPs and mimic the activities of AMPs (Lai et al. 2008). Ceragenins can be prepared in large quantities because of their simple structures. Additionally, they are not degraded by proteases because they do not have peptide structure. Multiple studies have indicated that ceragenins display broad-spectrum activities against both Gram positive and Gram negative bacteria including drug-resistant bacteria, biofilms, fungi and viruses (Bozkurt-Guzel et al. 2014a; Durnas et al. 2016; Olekson et al. 2017).Besides, some studies have shown that the toxicity of the ceragenins is not remarkable (Saha et al. 2008; Leszczyńska et al. 2013). 
It has been shown that ceragenins have different resistance mechanisms than colistin and can be used in colistin-resistant Klebsiella pneumoniae isolates (Hashemi et al. 2017). Further studies are needed to determine the efficacy of ceragenins against multi-drug resistant bacteria. Thus, we aimed in this study to determine the effects of ceragenins against some multidrug resistant (including colistin) Gram negative bacteria obtained from Medical Microbiology Laboratories of the Faculty of Medicine, Çanakkale Onsekiz Mart University, Çanakkale, Turkey and Istanbul Faculty of Medicine, Istanbul, Turkey.

\section{MATERIAL AND METHODS}

\section{Bacterial isolates}

A total of 17 clinically isolates including K. pneumoniae $(n=9)$, Morganella morganii $(n=1)$, Pseudomonas aeruginosa $(n=5)$ and Stenotrophomonas maltophilia $(n=2)$ isolated from various specimens were obtained from the Medical Microbiology Laboratories of the Faculty of Medicine, Çanakkale Onsekiz Mart University, Çanakkale, Turkey and Istanbul Faculty of Medicine, Istanbul, Turkey between 2006-2016. All isolates were identified by Vitek 2 (BioMerieux, France) or API20 NE System (BioMerieux, France). Escherichia coli ATCC 25922 and $P$. aeruginosa ATCC 27853 are used as quality control strains.

\section{Antimicrobial agents}

CSA-8, CSA-13, CSA-142 and CSA-192 were synthesized from cholic acid as previously described (Guan et al. 2000). Chemical structures of ceragenins were shown in Figure 1. Meropenem, cefotaxime, colistin and levofloxacin were obtained from manufacturer (Sigma-Aldrich). Stock solutions from dry powders were prepared at a concentration of 5120 $\mu \mathrm{g} / \mathrm{mL}$ and stored at $-80^{\circ} \mathrm{C}$ and used within 6 months of preparation.

\section{Antimicrobial susceptibility testing}

Mueller-Hinton broth (MHB; Difco Laboratories, Detroit, Mich., USA) supplemented with divalent cations to a final concentration of $25 \mathrm{mg}$ of $\mathrm{Mg}^{2+}$ and $50 \mathrm{mg}$ of $\mathrm{Ca}^{2+}$ per liter (CAMHB) was used for in vitro antimicrobial activity studies and Tryptic soy agar (TSA; Difco Laboratories) were used for colony counts. Minimum inhibitory concentrations (MICs) and Minimum bactericidal concentrations (MBCs) were determined by a microdilution method according to the International Organization for Standardization (ISO) (ISO 20776-1, 2006). Serial two-fold dilutions of antibiotics were prepared in $\mathrm{CAMHB}$ in the test tray. A final concentration of $5 \times 10^{5} \mathrm{CFU} / \mathrm{mL}$ of inoculum was added. The trays were incubated at $37^{\circ} \mathrm{C}$ for $18-20 \mathrm{~h}$. The MIC value was determined as the lowest concentration of antibiotics that led no visible bacterial growth. MBCs were determined at the conclusion of the incubation period by removing two $0.01 \mathrm{~mL}$ samples from each well demonstrating no visible growth and plating onto TSA. The MBCs were defined as the lowest concentration of antibiotic giving at least $99.9 \%$ (three-log) reduction of the initial inocula. All experiments were performed in duplicate.

\section{RESULTS}

According to the results, all isolates were evaluated considering EUCAST limits and most of them were found to be resistant to colistin, meropenem, cefotaxime and levofloxacin (Table 1) (EUCAST, 2018a). If an isolate is non-susceptible to at least one agent in three or more antimicrobial classes, it is defined as multidrug resistant (MDR) (Magiorakos et al. 2012). Accordingly, most of the tested isolates in this study (excluding two K. pneumoniae isolates and one P. aeruginosa isolate) were defined as MDR. Two K. pneumoniae isolates and one $P$. aeruginosa isolate were resistant to at least one agent in the two classes, but intermediate to meropenem (MIC: $8 \mu \mathrm{g} / \mathrm{mL}$ ). CSAs, especially CSA-13 displayed considerable inhibitory effect (MIC: 8-64 $\mu \mathrm{g} / \mathrm{mL}$ ) against K. pneumoniae, M. morganii, $P$. aeruginosa and S. maltophilia isolates even though resistant to colistin (MIC: 16->256 mL) (Table 2). The least effective agent was CSA-8 (MIC: $>128 \mu \mathrm{g} / \mathrm{mL}$ ) against all microorganisms. CSA-142 (MIC: 16-64 $\mu \mathrm{g} / \mathrm{mL}$ ) showed moderate activity. Antibacterial activity of CSA-192 was determined from $32 \mu \mathrm{g} /$

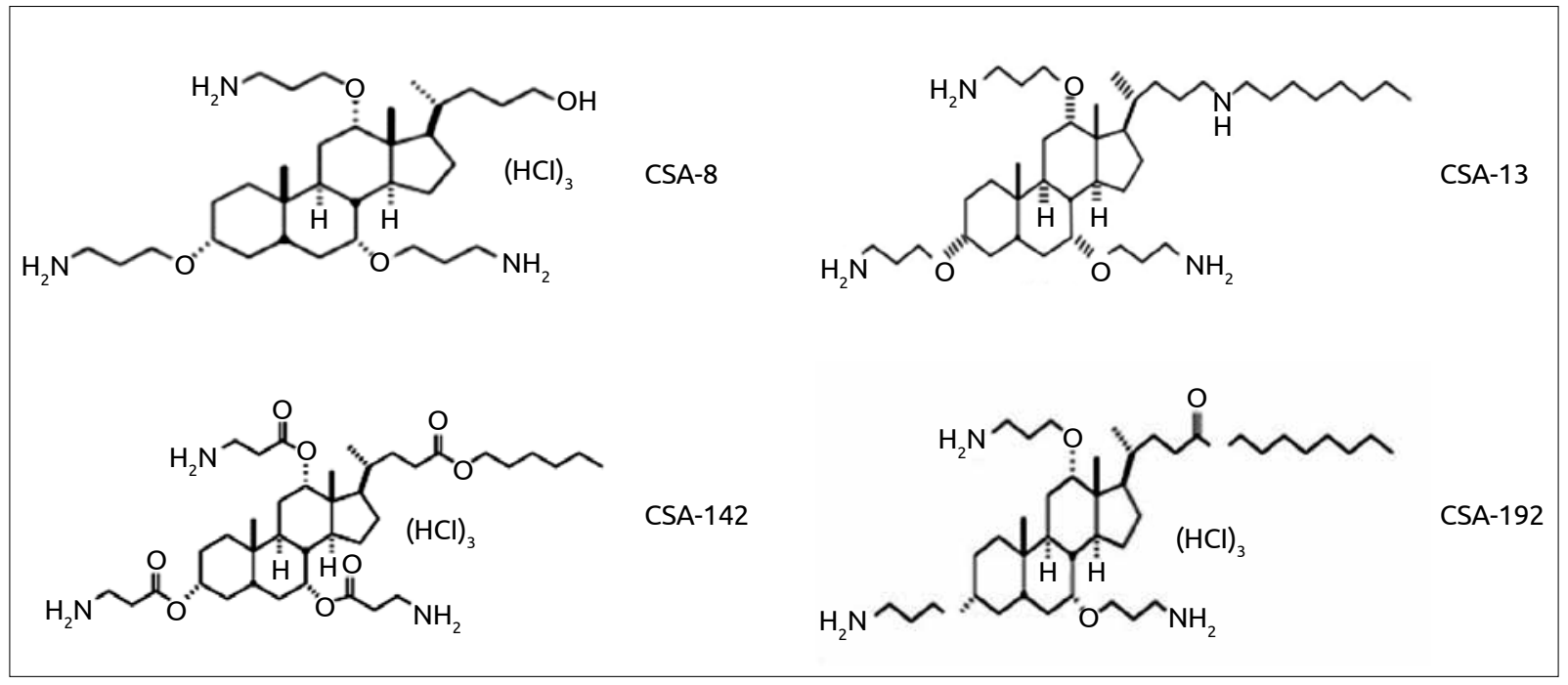

Figure 1. Chemical structures of ceragenins 
$\mathrm{mL}$ to $>128 \mu \mathrm{g} / \mathrm{mL}$. Among microorganisms, all CSAs showed the lowest activity against M. morganii (one isolate). The MBCs were generally equal to or two fold greater than those of the MICs. All quality control results were within acceptable ranges reported in the EUCAST quality control tables (EUCAST, 2018b).

Table 1. In vitro antibacterial activities of antibiotics against various Gram negative bacteria

\begin{tabular}{|c|c|c|c|c|c|c|c|c|}
\hline \multirow[b]{3}{*}{ Microorganisms } & \multicolumn{2}{|c|}{ Colistin } & \multicolumn{2}{|c|}{ Meropenem } & \multicolumn{2}{|c|}{ Cefotaxime } & \multicolumn{2}{|c|}{ Levofloxacin } \\
\hline & MIC & MBC & MIC & MBC & MIC & MBC & MIC & MBC \\
\hline & \multicolumn{8}{|c|}{$\mu \mathrm{g} / \mathrm{mL}$} \\
\hline K. pneumoniae 1 & 256 & 256 & 32 & 128 & $>128$ & $>128$ & 8 & 8 \\
\hline K. pneumoniae 2 & $>256$ & $>256$ & 8 & 8 & $>128$ & $>128$ & 8 & 8 \\
\hline K. pneumoniae 3 & 32 & 32 & 32 & 32 & $>128$ & $>128$ & 16 & 16 \\
\hline K. pneumoniae 4 & 32 & 32 & 32 & 64 & $>128$ & $>128$ & 32 & 32 \\
\hline K. pneumoniae 5 & 32 & 32 & 16 & 16 & $>128$ & $>128$ & 32 & 32 \\
\hline K. pneumoniae 6 & $>256$ & $>256$ & 64 & 64 & $>128$ & $>128$ & 32 & 64 \\
\hline K. pneumoniae 7 & 32 & 32 & 8 & 8 & $>128$ & $>128$ & 32 & 32 \\
\hline K. pneumoniae 8 & 32 & 64 & 16 & 16 & $>128$ & $>128$ & 16 & 16 \\
\hline K. pneumoniae 9 & 64 & 64 & 64 & 128 & $>128$ & $>128$ & 32 & 32 \\
\hline M. morganii & $>256$ & $>256$ & 16 & 16 & 128 & 128 & 16 & 32 \\
\hline P.aeruginosa 1 & 32 & 32 & 32 & 32 & 128 & 128 & 128 & 128 \\
\hline P. aeruginosa 2 & 16 & 16 & 32 & 32 & $>128$ & $>128$ & 8 & 8 \\
\hline$P$ aeruginosa 3 & 32 & 32 & 16 & 32 & $>128$ & $>128$ & 32 & 64 \\
\hline P. aeruginosa 4 & 32 & 32 & 16 & 32 & $>128$ & $>128$ & $>128$ & $>128$ \\
\hline P. aeruginosa 5 & 32 & 32 & 8 & 16 & $>128$ & $>128$ & 64 & 64 \\
\hline S. maltophilia 1 & 128 & $>128$ & $>128$ & $>128$ & $>128$ & $>128$ & 16 & 64 \\
\hline S. maltophilia 2 & 32 & 32 & 128 & 128 & $>128$ & $>128$ & 16 & 32 \\
\hline
\end{tabular}

Table 2. In vitro antibacterial activities of ceragenins against various Gram negative bacteria

\begin{tabular}{|c|c|c|c|c|c|c|c|c|}
\hline \multirow[b]{3}{*}{ Microorganisms } & \multicolumn{2}{|c|}{ CSA-8 } & \multicolumn{2}{|c|}{ CSA-13 } & \multicolumn{2}{|c|}{ CSA-142 } & \multicolumn{2}{|c|}{ CSA-192 } \\
\hline & MIC & MBC & MIC & MBC & MIC & MBC & MIC & MBC \\
\hline & \multicolumn{8}{|c|}{$\mu \mathrm{g} / \mathrm{mL}$} \\
\hline K. pneumoniae 1 & $>128$ & $>128$ & 8 & 16 & 64 & 64 & 64 & 64 \\
\hline K. pneumoniae 2 & $>128$ & $>128$ & 16 & 16 & 64 & 64 & 64 & 64 \\
\hline K. pneumoniae 3 & $>128$ & $>128$ & 8 & 8 & 64 & 64 & 64 & 64 \\
\hline K. pneumoniae 4 & $>128$ & $>128$ & 16 & 32 & 32 & 32 & 128 & 128 \\
\hline K. pneumoniae 5 & $>128$ & $>128$ & 16 & 16 & 32 & 32 & 64 & 64 \\
\hline K. pneumoniae 6 & $>128$ & $>128$ & 16 & 16 & 32 & 32 & 128 & 128 \\
\hline K. pneumoniae 7 & $>128$ & $>128$ & 8 & 8 & 64 & 64 & 64 & 64 \\
\hline K. pneumoniae 8 & $>128$ & $>128$ & 16 & 16 & 16 & 16 & 64 & 64 \\
\hline K. pneumoniae 9 & $>128$ & $>128$ & 16 & 16 & 32 & 64 & 128 & 128 \\
\hline M. morganii & $>128$ & $>128$ & 64 & 64 & 64 & 64 & 128 & 128 \\
\hline Paeruginosa 1 & $>128$ & $>128$ & 16 & 16 & 32 & 32 & 128 & $>128$ \\
\hline$P$ aeruginosa 2 & $>128$ & $>128$ & 8 & 8 & 32 & 32 & 32 & 32 \\
\hline P. aeruginosa 3 & $>128$ & $>128$ & 16 & 16 & 32 & 32 & 128 & 128 \\
\hline P. aeruginosa 4 & $>128$ & $>128$ & 16 & 32 & 32 & 32 & 128 & 128 \\
\hline P.aeruginosa 5 & $>128$ & $>128$ & 16 & 32 & 32 & 64 & 128 & 128 \\
\hline S. maltophilia 1 & $>128$ & $>128$ & 16 & 16 & 64 & 64 & 64 & 64 \\
\hline S. maltophilia 2 & $>128$ & $>128$ & 64 & 64 & 64 & 128 & 64 & 128 \\
\hline
\end{tabular}




\section{DISCUSSION}

The emergence of MDR microorganisms, which are not affected by most of the drugs, is a growing health threat all over the world. The World Health Organization has published a list of priority pathogens resistant to antimicrobials in order to assist in the research and development of new and effective antibacterial agents. One of the most important outputs of the report is that researchers should be focused on the discovery and development of active new antibiotics against multi-drug resistant Gram negative bacterial strains. According to this report, carbapenem-resistant $P$. aeruginosa, K. pneumoniae, M. morganii are among the pathogens against which urgent precautions should be taken (WHO, 2017). Therefore, our study involves multi-drug resistant Gram negative microorganisms, including carbapenem-resistant P. aeruginosa, K. pneumoniae, M. morganii.

As reported previously, ceragenins have potent antimicrobial activity (Bozkurt-Güzel et al. 2014a; Bozkurt-Guzel et al. 2014b; 2014b; Durnas et al. 2016; Olekson et al. 2017). Hashemi et al. (2017) found that CSA-13 (MIC: $2-6 \mu \mathrm{g} / \mathrm{mL}$ ) and CSA-142 (MIC: 2-16 $\mu \mathrm{g} / \mathrm{mL}$ ) had significant antimicrobial effects and CSA44 and CSA-131 were bactericidal against colistin resistant K. pneumoniae strains. Furthermore, it was also reported that ceragenins (CSA-44 and CSA-131) retained bactericidal activity against colistin-resistant bacteria. Similarly, the data shown here established that CSA-13 and CSA-142 had higher activity than other ceragenins against colistin resistant $K$. pneumoniae strains and CSA-13 (MIC: 8-16 $\mu \mathrm{g} / \mathrm{mL}$ ) had lower MIC value than CSA-142 (MIC: 16-64 $\mu \mathrm{g} / \mathrm{mL}$ )

In the study performed by Vila-Farrés et al. (2015) regarding the activity of ceragenins against $P$. aeruginosa, it was determined that CSA-13 had the same MIC values against both colistin resistant and non-resistant strains. Chin et al. (2008) showed that CSA-13 MIC 50 was $16 \mu \mathrm{g} / \mathrm{mL}$ and had potential synergistic activity against multi-drug resistant $P$. aeruginosa. In this study, CSA-13 showed similar activity (MIC: $8-16 \mu \mathrm{g} / \mathrm{mL}$ ) against colistin resistant $P$. aeruginosa strains. According to these results, it was concluded that colistin resistance did not alter the effect of ceragenins. In another study, erythromycin-ceragenin combination against multi-drug resistant pathogens was investigated and it was shown that CSA-13 increased the activity of erythromycin by depolarizing the bacterial outer membrane. Moreover, the toxicity of CSA-13 was determined to be insignificant (Saha et al. 2008). Our study also demonstrated high antimicrobial activity of CSA-13 against multi-drug resistant $P$. aeruginosa.

To our knowledge, there is no study evaluating the activities of ceragenins against M. morganii and S. maltophilia. The study mentioned herein showed that the highest MIC value of the tested ceragenins was against M. morganii strain (MIC: 64-> 128 $\mu \mathrm{g} / \mathrm{mL}$ ). Outer membranes of these microorganisms can be a barrier for ceragenins and therefore they do not have low MIC values (Pollard et al. 2012).

According the data in Table 2, CSA-8 was found to be the least active agent. Previous studies also have shown that CSA-8 was more effective against Gram positive bacteria than Gram negative bacteria and fungi (Bozkurt-Güzel et al. 2014a; BozkurtGuzel et al. 2014b). The low activity of CSA-8 may be due to the lack of the hydrophobic side chain and being more hydrophilic than the other compounds.

Consequently, in the present study, multiple drug resistance was detected in most of the tested bacteria. Apparently, new agents are needed to treat the diseases caused by these bacteria. Our study showed that ceragenins, especially CSA-13, are promising agents against colistin-resistant Gram negative strains. However, additional studies are also needed to determine activity and safety of ceragenins.

Peer-review: Externally peer-reviewed

Author Contributions: Concept - C.B.G., O.O.; Design - C.B.G.; Supervision - C.B.G.; Resource - C.B.G.; Materials - P.B.S., A.A., Z.E.; Data Collection and/or Processing - P.B.S., A.A., Z.E. O.O.; Analysis and/or Interpretation - C.B.G., O.O.; Literature Search - C.B.G., O.O.; Writing - C.B.G., O.O.; Critical Reviews - C.B.G., P.B.S

Conflict of Interest: The authors have no conflict of interest to declare.

Financial Disclosure: The authors declared that this study has received no financial support.

\section{REFERENCES}

- $\quad$ Ah YM, Kim AJ, Lee JY (2014). Colistin resistance in Klebsiella pneumoniae. Int J Antimicrob Agents, 44(1): 8-15. [CrossRef]

- $\quad$ Band VI, Weiss DS (2014). Mechanisms of antimicrobial peptide resistance in Gram-negative bacteria. Antibiotics 4(1): 18-41. [CrossRef]

Bolla JM, Alibert-Franco S, Handzlik J, Chevalier J, Mahamoud A Boyer G, Kieć-Kononowicz K (2011). Strategies for bypassing the membrane barrier in multidrug resistant Gram-negative bacteria. FEBS lett 585(11): 1682-1690. [CrossRef]

- $\quad$ Bozkurt-Guzel C, Savage PB, Akcali A, Ozbek-Celik B (2014a). Potential synergy activity of the novel ceragenin, CSA-13, against carbapenem-resistant Acinetobacter baumannii strains isolated from bacteremia patients. Biomed Res Int 2014: 710273. [CrossRef] Bozkurt-Güzel Ç, Tüysüz M, Inan N, Savage PB (2014b). Katyonik steroid antibiyotiklerden olan CSA-8, CSA-13, CSA-44, CSA-131 ve CSA-138'in, kan kültürlerinden izole edilen Candida albicans suşlarına karşı antifungal etkilerinin araştırılması. Ankem Derg 28(1): 8-13. [CrossRef]

- Chin JN, Jones RN, Sader HS, Savage PB, Rybak MJ (2008). Potential synergy activity of the novel ceragenin, CSA-13, against clinical isolates of Pseudomonas aeruginosa, including multidrugresistant P. aeruginosa. J Antimicrob Chemother 61(2): 365-370. [CrossRef]

- Döşler, S (2017). Antimicrobial peptides: Coming to the end of antibiotic era, the most promising agents. Istanbul J Pharm 47(2): 72-76. [CrossRef]

- Durnaś B, Wnorowska U, Pogoda K, Deptuła P, Wątek M, Piktel E (2016). Candidacidal activity of selected ceragenins and human cathelicidin LL-37 in experimental settings mimicking infection sites. PloS One 11(6): e0157242. [CrossRef]

- $\quad$ Guan Q LC, Schmidt EJ, Boswell JS, Walsh JP, Allman GW (2000) Preparation and Characterization of Cholic Acid-Derived Antimicrobial Agents with Controlled Stabilities. Org lett 2(18): $2837-$ 2840. [CrossRef] 
- Hashemi MM, Rovig J, Weber S, Hilton B, Forouzan MM, Savage PB (2017). Susceptibility of colistin-resistant, Gram-negative bacteria to antimicrobial peptides and ceragenins. Antimicrob Agents Chemother 61: e00292-17. [CrossRef]

- International Organization for Standards. 15 November 2006, posting date. Susceptibility testing of infectious agents and evaluation of performance of antimicrobial susceptibility testing devices. 1. Reference method for testing the in vitro activity of antimicrobial agents against rapidly growing anaerobic bacteria involved in infectious diseases. ISO 20776-1. International Organization for Standards, Geneva, Switzerland.

- Lai XZ, Feng Y, Pollard J, Chin JN, Rybak MJ, Bucki R, Epand RF, Epand RM, Savage PB (2008). Ceragenins: cholic acid-based mimics of antimicrobial peptides. Acc Chem Res 41(10): 1233-1240. [CrossRef]

- Leszczyńska K, Namiot D, Byfield FJ, Cruz K, Zendzian-Piotrowska M, Fein DE, Savage PB, Diamond S, McCulloch CA, Janmey PA, Bucki R (2013). Antibacterial activity of the human host defence peptide LL-37 and selected synthetic cationic lipids against bacteria associated with oral and upper respiratory tract infections. $J$ Antimicrob Chemother 68: 610-618. [CrossRef]

- Magiorakos AP, Srinivasan A, Carey RB, Carmeli Y, Falagas ME, Giske CG, Paterson DL (2012). Multidrug-resistant, extensively drug-resistant and pandrug-resistant bacteria: an international expert proposal for interim standard definitions for acquired resistance. Clin Microbiol Infect 18(3): 268-281. [CrossRef]

- Marchaim D, Chopra T, Pogue JM, Perez F, Hujer AM, Rudin S, Endimiani A, Navon-Venezia S, Hothi J, Slim J, Blunden, C (2011). Outbreak of colistin-resistant, carbapenem-resistant Klebsiella pneumoniae in metropolitan Detroit, Michigan. Antimicrob Agents Chemother 55(2): 593-599. [CrossRef]

- Olekson MA, You T, Savage PB, Leung KP (2017). Antimicrobial ceragenins inhibit biofilms and affect mammalian cell viability and migration in vitro. FEBS Open Bio 7(7): 953-967. [CrossRef]

- Otter JA, Doumith M, Davies F, Mookerjee S, Dyakova E, Gilchrist M, Brannigan ET, Bamford K, Galletly T, Donaldson H, Aanensen DM, Ellington MJ, Hill R, Turton JF, Hopkins KL, Woodford N, Holmes A, Aanensen DM (2017). Emergence and clonal spread of colistin resistance due to multiple mutational mechanisms in carbapenemase-producing Klebsiella pneumoniae in London. Sci $\operatorname{Rep}$ 7(12711): 1-8. [CrossRef]
Pollard JE, Snarr J, Chaudhary V, Jennings JD, Shaw H, Christiansen B, Wright J, Jia W, Bishop RE, Savage PB (2012). In vitro evaluation of the potential for resistance development to ceragenin CSA-13. J Antimicrob Chemother 67(11): 2665-2672. [CrossRef]

Rojas LJ, Salim M, Cober E, Richter SS, Perez F, Salata RA, Kalayjian RC, Watkins RR, Marshall S, Rudin SD, Domitrovic TN, Hujer AM, Hujer KM, Doi Y, Kaye K, Evans S, Fowler VG, Bonomo RA (2016). Colistin resistance in carbapenem-resistant Klebsiella pneumoniae: laboratory detection and impact on mortality. Clin Infect Dis 64(6): 711-718. [CrossRef]

- Rossi F, Girardello R, Cury AP, Di Gioia TSR, Almeida JND, Duarte AJDS (2017). Emergence of colistin resistance in the largest university hospital complex of São Paulo, Brazil, over five years. Braz J Infect Dis 21(1): 98-101. [CrossRef]

Saha S, Savage PB, Bal M (2008). Enhancement of the efficacy of erythromycin in multiple antibiotic-resistant Gram-negative bacterial pathogens. J App/ Microbio/ 105(3): 822-828. [CrossRef]

- Sonnevend Á, Ghazawi A, Alqahtani M, Shibl A, Jamal W, Hashmey R, Pal T (2016). Plasmid-mediated colistin resistance in Escherichia coli from the Arabian Peninsula. Int J Infect Dis 50: 85-90. [CrossRef]

- The European Committee on Antimicrobial Susceptibility Testing (EUCAST) (2018a). Breakpoint tables for interpretation of MICs and zone diameters. Version 8.0. http://www.eucast.org

- The European Committee on Antimicrobial Susceptibility Testing (EUCAST) (2018b). Routine and extended internal quality control for MIC determination and disk diffusion as recommended by EUCAST. Version 8.0. http://www.eucast.org

- Vila-Farrés X, Callarisa AE, Gu X, Savage PB, Giralt E, Vila J (2015). CSA-131, a ceragenin active against colistin-resistant Acinetobacter baumannii and Pseudomonas aeruginosa clinical isolates. Int J Antimicrob Agents 46(5): 568-571. [CrossRef]

- World Health Organization (WHO) (2017). Global priority list of antibiotic-resistant bacteria to guide research, discovery, and development of new antibiotics. Geneva: World Health Organization.

- Zaman SB, Hussain MA, Nye R, Mehta V, Mamun KT, Hossain N (2017). A review on antibiotic resistance: alarm bells are ringing. Cureus 9(6): e1403. [CrossRef] 